\title{
MERIT SYSTEM DALAM MEWUJUDKAN TRANSPARANSI PEMBINAAN KARIER APARATUR SIPIL NEGARA
}

\author{
Nurwita Ismail \\ Fakutlas Hukum Universitas Gorontalo \\ Jalan A.A Wahab (Jalan Jend. Sudirman) No. 247 Limboto Gorontalo \\ Email: nhurwita.ismail@gmail.com
}

\begin{abstract}
The Merit System is a reflection of professional staffing management where the placement of employees and officials uses performance competencies and track records as a means of measuring appointments. But so far the system merit has not been fully implemented even though if this system is implemented, it can produce qualified official figures and have good performance other than that it will not interfere with internal conditions because it has continuity with the old officials. Practices that occur are politicization of the State Civil Apparatus. Merit violations are usually like people being demoted without clear reasons and mutations. New regional heads usually dismantle their employees with people he knows. Everything is still related to retribution and revenge, so that this article is carried out with the aim of knowing how the implementation of the Merit System in ASN career development and the factors that influence the implementation of Merit System can realize the transparency of ASN career coaching using Qualitative analysis methods. So that it is expected to contribute ideas to the government in the study and implementation of a better Merit System.
\end{abstract}

Keywords: Merid System and State Civil Apparatus

\begin{abstract}
Abstrak
Merit sistem merupakan cerminan manajemen kepegawaian yang profesional dimana penempatan pegawai dan pejabat menggunakan kompetensi kinerja dan track record sebagai alat ukur pengangkatan. Namun sejauh ini merit sistem belum sepenuhnya dilakukan padahal Jika sistem ini diterapkan, dapat menghasilkan figur pejabat yang mumpuni dan memiliki kinerja bagus selain itu tidak akan mengganggu kondisi internal karena memiliki kesinambungan dengan pejabat lama. Praktek-praktek yang terjadi adanya politisasi terhadap Aparatur Sipil Negara. Pelanggaran Merit itu biasanya seperti orang diturunkan jabatannya tanpa alasan yang jelas dan mutasi. Kepala daerah baru biasanya membongkar pegawainya dengan orang-orang yang dia kenal. Semuanya masih berkaitan dengan balas budi dan balas dendam, sehingganya tulisan ini dilakukan dengan tujuan mengetahui Bagaimana implementasi Merit System dalam pembinaan karier ASN serta Faktor yang mempengaruhi penerapan Merit System dapat mewujudkan transparansi pembinaan karier ASN dengan menggunakan Metode analisis Kualitatif. Sehingga diharapkan dapat memberikan sumbangan pemikiran terhadap pemerintah dalam pengkajian dan pelaksanaan Merid Sytem kearaha yang lebih baik.
\end{abstract}

Kata Kunci: Merid System, Aparatur Sipil Negara 


\section{PENDAHULUAN}

Dalam era globalisasi dewasa ini salah satu tantangan yang dihadapi adalah bagaimana menampilkan Aparatur Sipil Negara yang profesional, memiliki keandalan dalam pelaksanaan tugas sehingga terlaksana dengan mutu tinggi, waktu yang tepat, cermat, dan dengan prosedur yang mudah dipahami dan diikuti oleh masyarakat. Peristiwa terburuk yang membawa kondisi perekonomian kita terpuruk saat ini dan sulit bangkit kembali, merupakan salah satu faktor kesadaran bagi kita semua untuk kembali menata system pemerintahan yang ada untuk menjadi lebih baik lalih. Salah satu unsur pemerintahan yang memperoleh perhatian dalam upaya reformasi itu ialah penataan aparatur sipil negara (ASN) yang meliputi kelembagaan birokrasi pemerintahan, system dan penataan manajemen sumber daya pegawai.

Upaya Menpan dan Reformasi Birokrasi dalam memberikan penghargaan bagi ASN yang berprestasi dalam berinovasi membuktikan betapa seriusnya pemerintah dalam menanggapi masalah profesionalisme ASN dimana salah satu langkah yang dilakukan dengan melaksanakan Merit System yang ditetapkan dalam Undang-Undang Nomor 5 Tahun 2014 tentang Aparatur Sipil Negara (ASN). UU ini secara tegas melaksanakan dan mewujudkan sistem merit dalam menata manajemen pemerintahan. Merit System dalam praktik pemerintahan sudah lama dikenal dan dilaksanakan. Akan tetapi, perwujudannya jauh dari yang seharusnya terjadi.

Merit System merupakan penempatan seseorang dengan jabatan pimpinan tinggi berdasarkan kompetensi yang dimiliki. Namun praktek yang tejadi sekarang ini proses merit sytem sudah mulai terkontaminasi dengan praktekpraktek monopoli, terjadi sistem rekrutmen yang teridikasi pengaruh partai politik dan masih banyak lagi praktek lainnya yang mempengaruhi sytem ini tidak berjalan dengan baik. Undang-undang nomor 5 tahun 2014 tentang ASN dirasa masih kurang berkerja maksimal. Penerapan Merit Systerm dalam manajemen ASN sudah diterapkan di negara-negara maju. Oleh karena itu, diharapkan Indonesia dapat lebih meningkatkan kualitas dan kompetensi pejabat tinggi yang ada. Dengan Mesrit System tersebut, diharapkan nantinya tidak ada lagi penempatan jabatan pimpinan tinggi yang berdasarkan penilaian subjektif.

Merit sistem salah sebagai dasar berbasis kompetensi pegawai. Setiap pegawai sangat besar peluang kesempatan untuk berprestasi. Hal ini diawali dengan 
rekrutmen, pengembangan, penempatan dalam Job Promosi, sesuai pada uraian isi Undang-undang ASN pasal 70 ayat (1) "Bahwa setiap pegawai memiliki hak dan kesempatan untuk mengembangkan kompetensi. Yang artinya setiap pegawai pemerintah berhak mendapatkan pendidikan baik formal maupun informal ${ }^{1}$.

Buruknya indikator kinerja aparat pelayanan publik Aparatur Sipil Negara (ASN) di Indonesia, ditunjukan oleh pelayanan yang birokratif ; selain itu juga biaya yang tinggi (high cost economy); masih ada juga pungutan-pungutan, serta adanya perlakuan aparat yang bersikap sebagai pejabat ketimbang abdi masyarakat; dari segi pelayanan masih ada yang diskriminatif; lamban dalam memberikan pelayanan; kurang berminat dalam men-sosialisasikan program penting dan yang paling paranya lagi penempatan ASN tidak berdasarkan bidang ilmu yang dimiliki.tentunuya kondisi seperti ini harus perlu diperhatikan sehingganya dengan penerapan Merit System ini sekiranya dapat dilakukan dengan baik dan benar tanpa ada tindakan Korupsi,kolusi dan nepotisme sehingga kedepan keberadaan ASN benar-

1 Meyrina, R. S. A.” Implementasi Peningkatan Kinerja Melalui Merit Sistem Guna Melakanakan Undang-Undang Aparatur Sipil Negara No. 5 Tahun 2014 Di Kementerian Hukum Dan HAM" Pedagogia, 10(no.2, juli 2016), 175185. benar menampilkan aparatur sipil negara yang profesional dibidangnya. tujuan dari reformasi birokrasi sendiri adalah menciptakan birokrasi pemerintah yang profesional dengan karakteristik, berintegrasi, berkinerja tinggi, bebas dan bersih KKN, mampu melayani publik, netral, sejahtera, berdedikasi, dan memegang teguh nilai-nilai dasar dan kode etik aparatur negara ${ }^{2}$.

Selain penerapan merit system dalam pemerintahan, Masalah kedisiplinan pegawai menjadi faktor penting yang sangat mempengaruhi keberhasilan organisasi pemerintah. Seorang Aparatur Sipil Negara (ASN) tidak akan bisa bertanggung jawab atas pekerjaannya apabila kurang disiplin terhadap aturan - aturan yang berlaku. Disiplin ASN adalah kesanggupan ASN untuk menaati kewajiban dan menghindari larangan yang ditentukan dalam peraturan perundang-undangan dan atau peraturan kedinasan yang apabila tidak ditaati atau dilanggar akan dijatuhi hukuman disiplin ${ }^{3}$.

\section{RUMUSAN MASALAH}

Berdasarkan latar belakang yang diuraikan diatas, maka dapat dirumuskan

${ }^{2}$ Hanif. "Sistem kompensasi pns berbasis kinerja. Ekonomi Dan Bisnis Islam”, 1(April) 2016, 92-104.

${ }^{3}$ Marthen, R., \& Polidu, I.” Kepegawaian Daerah Kabupaten Gorontalo Utara" Gorontalo Law Review. Volume 1 April 2018. 
peramasalahan

Bagaimana

implementasi Merit

System dalam

pembinaan karier Aparatur Sipil Negara

berdasarkan UU No. 5 Tahun 2014?

\section{METODE PENELITIAN}

Dalam menjawab rumusah permasalahan penulis menggunakan pemetode penelitian dengan jenis penelitan normatif. Metode penelitian normatif akan dilakukan dengan menggunakan bahan bahan hukum sekunder. Teknik Pengumpulan Data dengan Melakukan studi kepustakaan yaitu mempelajari bukubuku/literatur, jurnal atau penelitian terdahulu serta peraturan perundangundangan yang berhubungan dengan kajian yang penulis susun dalam jurnal ini dengan cara membaca, mengutip, menyalin dan menganalisa. Sedangkan Teknik Analisis data dilakukan secara kualitatif. Analisis kualitatif artinya menguraikan data secara bermutu dalam bentuk kalimat yang teratur, runtun, logis, tidak tumpang tindih, dan efektif.

\section{PEMBAHASAN}

Implementasi Merit System dalam

Pembinaan Karier Aparatur Sipil

\section{Negara Berdasarkan UU No. 5 Tahun}

2014

Sistem merit menurut konsepsi disiplin ilmu merupakan suatu sistem manajemen kepegawaian yang menekankan pertimbangan dasar kompetensi bagi calon yang akan diangkat, ditempatkan, dipromosi, dan dipensiun sesuai UndangUndang yang berlaku. Kompetensi calon itu mengandung arti calon harus punya keahlian dan profesionalisme sesuai kebutuhan jabatan yang akan dipangku. Kompetensi, keahlian dan profesionalistik calon menjadi pertimbangan utama. Sistem merit berasal dari kata merit atau manfaat atau meritokrasi sebenarnya menunjukkan kepada bentuk sistem politik yang memberikan penghargaan lebih kepada mereka yang berprestasi atau berkemampuan yang dapat dipakai untuk menentukan suatu jabatan tertentu ${ }^{4}$.

Realita yang terjadi, Merit System dilaksanakan, tetapi pelaksanaannya masih banyak terkontaminasi oleh praktekpraktek KKN dan Politik. Proses pengangkatan calon secara diam-diam dilakukan tidak sesuai dengan disiplin ilmu. Kompetensi calon diganti menjadi kepentingan pemegang kekuasaan. Keahlian dan profesionalisme menjadi

Negara No. 5 Tahun 2014 Di Kementerian Hukum Dan HAM" Pedagogia, 10(no.2, juli 2016), 175185. 
sebaliknya, sesuai dengan persepsi dan keinginan pemegang kekuasaan serta penempatan ditentukan oleh pertimbangan kedekatan calon dengan pemegang kekuasaan.

Cara melaksanakan Merit System seperti ini berlangsung lama dalam praktik pemerintahan, lebih-lebih pada pemerintahan Orde Baru yang berlangsung hampir 32 tahun. Bahkan, sisa-sisa pemerintahan Orde Baru masih terasa dipraktikkan sampai sekarang. Itulah sebabnya, pada 2014, dengan dipelopori Komisi II DPR, terbentuk UU ASN yang sarat dengan upaya menegakkan sistem merit ini. Semua berharap Undang-undang No. 5 tahun 2014 tentang ASN ini mampu memberikan dampak positif terhadap perubahan sistem manajerial pelayanan publik. Tidak sampai disitu, pada tahun 2017 bertempat di Hotel Santika, Depok, Komisi Aparatur Sipil Negara (KASN) melakukan penyusunan Pedoman Penilaian Mandiri Penerapan Sistem Merit dalam Manajemen Aparatur Sipil Negara. Pedoman ini didasari oleh Undang-Undang Nomor 5 Tahun 2014 tentang Aparatur Sipil Negara ${ }^{5}$.

Penyusunan pedoman tersebut dilakukan agar dapat menjadi acuan baku bagi instansi pemerintah dalam pelaksanaan penilaian mandiri penerapan Merit System agar dapat berjalan efektif dan akuntabel. Pedoman penilaian mandiri tersebut merupakan bagian dari penegakan Merit System, kode etik, nilai dasar, kode prilaku dan netralitas, khususnya pada jajaran pemerintahan dan kalangan Aparatur Sipil Negara (ASN). Penyusunan pedoman ini sangatah diperlukan karena penerapan system merit versi Indonesia akan sangat berbeda dengan definisi system merit secara universal.

Komisi Aparatur Sipil Negara (KASN) adalah lembaga negara yang menjamin terciptanya aparatur berkelas, profesional, berintegritas, dan berkinerja tinggi, yang anti kolusi dan nepotisme. Selain permasalahan yang diuraikan diatas, diharapkan kepada panitia penerimaan calon kiranya mampu menjaring ASN yang memiliki kwalitas dalam Sumber Daya Manusia, ASN sebagai SDM yang mengelola pelayanan publik seharusnya memiliki kualitas yang tepat dan benar sehingganya dirasa banwa penerapan Merit System ini sangat tepat dalam mengatasi permasalahan serta kekahwatiran masyarakat.
${ }^{5}$ Undang-Undang Nomor 5 Tahun 2014 tentang Aparatur Sipil Negara 
Dengan pengajian dan penerapan Merit System secara tepat dan benar maka dapat menciptakan suatu sistem pemerintahan yang baik (Good Governance). Dalam penerapan Merit System ada beberapa hal yang harus diperhatikan diantaranya Pemberian Gaji, Pemerataan penghasilan dengan memperhatikan tingkat imflasi/kelemahan, penggajian kepada ASN sekitanya harus dibuatkan standar tertentu yang berbasis kinerja. Selain itu juga pemberlakuan reward dan punishmet sangat perlu dilakukan dalam kiat-kiat pembinaan dan pengembangan karir ASN.

Sistem pengembangan pegawai adalah suatu usaha untuk meningkatkan kemampuan teknis, teoritis, konseptual, dan moral karyawan sesuai dengan kebutuhan pekerjaan atau jabatan melalui pendidikan dan karyawan ${ }^{6}$. Maka salah satu langkah dalam melaksanakan Merit System yaitu dengan melakukan sistem pengembangan pegawai dengan keterampilan dengan melakukan diklat sehingga ASN menjadi termpil dibidanya dalam mengelola SDM yang ada. Kesadaran dan kemauan untuk

${ }^{6}$ Hasibuan, Malayu. "Manajemen Sumber Daya Manusia”. Edisi Revisi.Jakarta: PT Bumi Aksara. 2000.

${ }^{7}$ Marthen, R., \& Polidu, I.” Kepegawaian Daerah Kabupaten Gorontalo Utara" Gorontalo Law Review. Volume 1 April 2018. merubah hal tersebut diatas akan mudah dilakukan bilamana seorang pegawai negeri sipil mampu menggeser dan merobohkan dinding mental pembatas (mental block) yang ada pada dirinya. Mental block yang ada dalam pikiran seseorang inilah yang menghambat dirinya untuk mau bergerak dan mau berubah untuk mencapai impian, tujuan, harapan, keinginan ataupun perubahan yang lebih baik dalam kehidupannya ${ }^{7}$. Selain itu Pengukuran Prestasi Kerja perlu dilakukan yang berbasis revolusi mental, sebagai penjabaran Rencana Pembangunan Jangka Menengah Nasional (RPJMN) yang tertuang dalam NAWACITA Presiden Joko Widodo dan Wapres Jusuf Kalla. ${ }^{8}$

BKD merupakan instansi yang sangat berpengaruh terhadap keberlangsungan suatu pemerintahan. Pengumpulan, pengelolaan dan pengendalian data berbetuk database serta analisa data untuk penyusunan program kegiatan ASN merupakan tugas BKD sehingganya SDM yang ada di instransi tersebut memang benar-benar mereka yang berkompeten dibidangnya sesuai dengan

${ }^{8}$ Moonti, R. M., Ismail, N., Karepoan, J. K., \& Djanggih, H. “ Pelaksanaan Pengukuran Prestasi Kerja Terhadap Aparatur Sipil Negara (ASN) di Dinas Pertanian Provinsi Gorontalo". Jurnal Ilmiah Kebijakan Hukum, https://doi.org/10.30641/kebijakan.2018.V12.151161 
kualifikasi bidang ilmu yang tepat dan benar. Perencanaan strategis pada Badan Kepegawaian Daerah merupakan suatu sikap yg menentukan baik buruknya suatu sistem pemerintahan dalam segi pelayanan. Sehingga ASN yang direkrut memang benar-benar mereka yang memiliki SDM yang baik, dalam mempermudah kerja BKD kiranya penerapan Merit System merupakan langkah terbaik dan lebih efektif sesuai dengan amanat undang-undang.

Tidak efektifnya pelaksanaan Merit System salah satunya karena pendekatan kekuasaan dijalankan oleh pejabat pemerintah. Manajemen pemerintahan yang sentralistik lebih mengutamakan pendekatan kekuasaan atau otoritas yang dipegang oleh pemegang jabatan, lebihlebih jika pemegang jabatan itu pejabat politik dari parpol. Akibatnya, semua tergantung persepsi pemegang kekuasaan. Ketegasan dan loyalitas melaksanakan UU yang ada menjadi samar-samar sesuai dengan aspirasi politik yang menjadi dasar pertimbangan pemegang kekuasaan jabatan. Padahal jelas dalam UndangUndang Nomor 5 Tahun 2014 pasal 1 ayat (22) menyebutkan bahwa "Sistem Merit adalah kebijakan dan Manajemen ASN yang berdasarkan pada kualifikasi, kompetensi, dan kinerja secara adil dan wajar dengan tanpa membedakan latar belakang politik, ras, warna kulit, agama, asal usul, jenis kelamin, status pernikahan, umur, atau kondisi kecacatan ${ }^{9}$.

Benturan antara amanat Undangundang Nomor 5 Tahun 2014 dengan Politik kekuasaan inilah yang selama ini mewarnai sistem pemerintahan kita. Secara terminologi pemerintahan tanpa kekuasaan, bukan lagi menjadi pemerintahan yang berdaulat. Namun, kekuasaan yang selalu jadi andalan dalam sistem pemerintahan, tanpa melihat pendekatan lain yang aspiratif dan humanitif, akan banyak penyimpangan. Sebagian besar daerah di Indonesia masih banyak yang belum menerapkan Merit System. Sehingganya masih banyak pula dijumpai transaksi jual beli jabatan yang masih cukup besar. Melalui sistem ini diharapkan dapat menutup kemungkinan transaksi jual beli jabatan tersebut.

Berbagai upaya yang dilakukan pemerintah dalam melakukan perbaikan sistem pemerintahan dalam ASN, seperti Upaya pemerintah terhadap pembentukan Komisi Aparatur Sipil Negara (KASN). Dalam Pasal 27 Undang-undang Nomor 5 Tahun 2014 menyebutkan: 
"KASN merupakan lembaga nonstruktural yang mandiri dan bebas dari intervensi politik untuk menciptakan Pegawai ASN yang profesional dan berkinerja, memberikan pelayanan secara adil dan netral, serta menjadi perekat dan pemersatu bangsa" 10 .

Upaya KASN dalam mewujudkan perbaikan sistem Karier Aparatur Sipil Negara dengan melakukan penyusunan Pedoman Penilaian Mandiri Penerapan Sistem Merit dalam Manajemen Aparatur Sipil Negara. Pedoman ini didasari oleh Undang-Undang Nomor 5 Tahun 2014 tentang Aparatur Sipil Negara. Ini dilakukan agar dapat menjadi acuan baku bagi instansi pemerintah dalam pelaksanaan penilaian mandiri dalam penerapan system merit agar dapat berjalan efektif dan akuntabel $^{11}$. Dalam penerapan Merit Systerm sebagai wujud transparansi pembinaan karir ASN indikator penting yang terjadi saat ini adalah masih adanya kegiatan pemberhentian dan pemindahan pegawai ASN yang teridikasi adanya kepentingan para petinggi negara serta campur tangan parpol. Penulis tidak sepakat dengan adanya sistem pemindahan atau lebih dikenal dengan Rolling pegawai, sebab bagaimana bisa seseorang mampu dinilai profesional ketika keberadaannya

10 Ibid

${ }^{11}$ https://www.kasn.go.id/details/item/187penerapan-sistem-merit-dalam-manajemenaparatur-sipil-negara pada suatu instansi tidak menetap. Praktekpraktek pemindahan ini banyak dijumpai pada pemerintahan di daerah. Adanya rolling pegawai menujukan bahwa kinerja BKD masih kurang baik karena Perumusan kebijakan teknis bidang kepegawaian dalah tugas dari BKD.

Perlu dilakukan sosialisasi terkait dengan kejelasan pasal 68 Point $(1)^{12}$. Berdasarkan pasal tersebut, belum dapat dimengerti pada setiap pegawai secara individu menyangkut peningkatan kinerja:

a. Pegawai Negeri Sipil (PNS) diangkat didalam jabatan tertentu;

b. Sistem Merit berbasis kompetensi ditentukan perbandingan obyektif antara kompetensi, kualifikasi, professional pendidikan dan kemampuan pegawai terhadap tugas pokok organisasi;

c. Setiap jabatan dikelompokkan di dalam klasifikasi berdasarkan karakteristik, mekanisme, pola kerja;

d. Pegawai Negeri dapat dapat berpindah antar instansi: Pimpinan Tinggi (Esselon II melalui Assesment), Jabatan Administrasi, Jabatan Fungsional Pusat, dan

\footnotetext{
12 Undang-Undang Nomor 5 Tahun 2014 tentang Aparatur Sipil Negara
} 
Instansi Daerah berdasarkan kualifikasi, kompetensi, penilaian kinerja $^{13}$.

\section{PENUTUP}

\section{Kesimpulan}

Penerapan Merit System memiliki dua konsekuensi, yakni pertama: semua jabatan harus memiliki standar kompetensi dan Kedua: seluruh pejabat harus memahami tugas dan target kerjanya. Maksud konsekuensi ini adalah adanya kecakapan Aparatur Sipil Negara (ASN) terkait dengan jabatan yang direbutkan dalam agenda open recruitment melalui Merit System. Sedangkan mengenai konsekuensi kedua, para calon pemangku jabatan diharapkan paham mengenai garis besar tugas kerja yang akan diembannya. Oleh karena Merit System diharapkan mampu memilih kandidat yang tepat untuk mengisi jabatanjabatan starategis di kementerian, lembaga negara, dan pemerintahan daerah. selain itu, sesuai dengan amanat yang tertuang dalam Undang-Undang Nomor 5 Tahun 2014 tentang ASN sekiranya dipahami bahwa dalam penerapan Merit System perlu adanya lelang jabatan dan seleksi terbuka pada tataran birokrasi di daerah sehingga kecil

13 Meyrina, R. S. A.” Implementasi Peningkatan Kinerja Melalui Merit Sistem Guna Melakanakan Undang-Undang Aparatur Sipil kemungkinan terjadinya potendi korupsi,kolusi dan nepotisme (KKN).

\section{Saran}

1. Khusus untuk pemerintah yang ada didaerah kiranya dapat melaksanakan benar-benar Merit System ini serta mengurangi proses mutasi sehingga harapan menghasilkan figur pejabat yang mumpuni dan memiliki kinerja bagus dapat tercapai.

2. Konsep merit ini tidak akan berjalan dengan sempurna jika tidak dibarengi dengan pengawasan terhadap proses seleksi yang ketat sehingga dapat terjamin kaulifikasi dan legalitasnya.

\section{DAFTAR PUSTAKA}

\section{Buku}

Hastho Joko Utomo, Manajemen Sumber Daya Manusia, Yogyakarta, Ardan Media, 2007.

Hasibuan, Malayu. "Manajemen Sumber Daya Manusia". Edisi Revisi.Jakarta: PT Bumi Aksara. 2000.

Moeheriono. Pengkuran Kinerja Berbasis Kompetensi, Ghalia Indonesia, Bogor, 2009.

Amirudin Dan Zainal Asiki, 2012, Pengantar Metode Penelitian

Negara No. 5 Tahun 2014 Di Kementerian Hukum Dan HAM" Pedagogia, 10(no.2, juli 2016), 175185. 
Hukum. Cet-6 Jakarta; PT Rajagrafindo Persada.

\section{Peraturan Perundang-undangan}

Undang-undang Nomor 5 Tahun 2014 Tentang Aparatur Sipil Negara.

\section{Jurnal}

Hanif. (2016). Sistem kompensasi pns berbasis kinerja. Ekonomi Dan Bisnis Islam, 1(April), 92-104.

Marthen, R., \& Polidu, I. (2010). Kepegawaian Daerah Kabupaten Gorontalo Utara ., 1-14.

Meyrina, R. S. A. (2016). Implementasi Peningkatan Kinerja Melalui Merit Sistem Guna Melakanakan UndangUndang Aparatur Sipil Negara No. 5 Tahun 2014 Di Kementerian Hukum Dan HAM. Pedagogia, 10(no.2, juli 2016), 175-185. https://doi.org/10.1017/CBO97811074153 24.004

Moonti, R. M., Ismail, N., Karepoan, J. K., \& Djanggih, H. (2018). Pelaksanaan Pengukuran Prestasi Kerja Terhadap Aparatur Sipil Negara (ASN) di Dinas Pertanian Provinsi Gorontalo. Jurnal Ilmiah Kebijakan Hukum, 12(2), 151. https://doi.org/10.30641/kebijakan.2018.V 12.151-161

\section{Internet}

https://www.menpan.go.id/site/beritaterkini/enam-poin-penting-dalamsistem-merit

https://www.kasn.go.id/details/item/187penerapan-sistem-merit-dalammanajemen-aparatur-sipil-negara 